\title{
Hubungan Antara Depresi Dengan Perilaku Cybersex Pada Emerging Adult
}

\author{
ANDRE HENDARTO \& TRI KURNIATI AMBARINI*
}

Departemen Psikologi Klinis dan Kesehatan Mental, Fakultas Psikologi Universitas Airlangga

\begin{abstract}
ABSTRAK
Penelitian ini dilakukan karena cybersex sudah menjadi salah satu fenomena yang berkembang dalam masyarakat saat ini, dan hal ini memiliki dampak negatif bagi siapa saja yang melakukannya seperti muncul masalah dalam interaksi sosial, perkembangan emosional, aktivitas seksual menyimpang atau beresiko seperti pelecehan anak, prostitusi, maupun kejahatan cyber. Penulis memiliki hipotesis yaitu depresi berhubungan dengan perilaku cybersex pada emerging adult. Penelitian ini menggunakan metode penelitian kuantitatif korelasional dan menggunakan metode survei online. Penelitian ini dilakukan pada emerging adult sebanyak 216 orang dengan teknik purposive sampling. Alat ukur yang digunakan adalah Beck Depression Inventory II (BDI-II) dan tranlasi Internet Sex Screening Test (ISST). Teknik analisis menggunakan korelasi Spearman Rho dengan bantuan SPSS 22 for Windows. Hasil penelitian menunjukkan bahwa terdapat hubungan yang signifikan antara depresi dengan perilaku cybersex pada emerging adult dengan korelasi sebesar 0,267 dan signifikansi sebesar 0,000 ( $<<0,05)$. Semakin tinggi depresi maka cybersex juga akan meningkat.
\end{abstract}

Kata kunci: cybersex, depresi, emerging adult

\section{ABSTRACT}

This research was conducted because cybersex has become a growing phenomenon in today's society, and this has a negative impact on anyone who does it, such as problems in social interaction, emotional development, deviant or risky sexual activity such as child abuse, prostitution, or cyber crime. The author has a hypothesis that depression is related to cybersex behavior in emerging adults. This study uses correlational quantitative research methods and uses online survey methods. This research was conducted on 216 emerging adults with purposive sampling technique. The measuring instruments used were the Beck Depression Inventory II (BDI-II) and the Internet Sex Screening Test (ISST) translation. The analysis technique uses the Spearman Rho correlation with the help of SPSS 22 for Windows. The results showed that there was a significant relationship between depression and cybersex behavior in emerging adults with a correlation of 0.267 and a significance of $0.000(p<0.05)$. The higher the depression, the cybersex will also increase.

Keywords: cybersex, depression, emerging adult

Buletin Penelitian Psikologi dan Kesehatan Mental (BRPKM), 2021, Vol. 1(1), 262-267

*Alamat korespondensi: Fakultas Psikologi Universitas Airlangga, Kampus B Universitas Airlangga Jalan Airlangga 4-6 Surabaya 60286. Surel: tri.ambarini@psikologi.unair.ac.id

Naskah ini merupakan naskah dengan akses terbuka dibawah ketentuan the Creative Common Attribution License (CC-BY-4.0) (http://creativecommons.org/licenses/by/4.0), sehingga penggunaan, distribusi, reproduksi dalam media apapun atas artikel ini tidak dibatasi, selama sumber aslinya disitir dengan baik. 


\section{P E N D A H U L U A N}

Masa emerging adult adalah masa yang penting dalam perkembangan manusia dengan eksplorasi menjadi ciri khas utamanya. Eksplorasi yang dilakukan bisa dalam berbagai hal, termasuk dalam hal seksual. Cybersex menjadi salah bentuk eksplorasi seksual yang banyak dilakukan oleh emerging adult termasuk di Indonesia. Cybersex adalah kegiatan penyaluran dorongan seksual di ruang maya (internet) yang diwujudkan dengan berbagai perilaku seksual saat menggunakan komputer (Delmonico, 1997). Cybersex dapat menimbulkan dampak negatif seperti munculnya adiksi, masalah dalam interaksi sosial, perkembangan emosional, aktivitas seksual menyimpang seperti pelecehan anak, prostitusi, maupun kejahatan cyber (Juditha, 2020).

Dampak tersebut bisa terjadi sebagai akibat dari sexual script yang terbentuk pada pikiran, perasaan, dan motivasi individu yang melakukan cybersex. Hal-hal seperti demikian itu membuat cybersex dapat dikategorikan sebagai perilaku berisiko dan seharusnya dihindari, namun pada kenyataannya masih banyak pengguna internet terutama pada golongan emerging adult yang melakukan hal tersebut. Ada sekitar $60 \%$ pengguna internet mengunjungi situs atau website yang bersifat seksual dan $87 \%$ mahasiswa di Amerika melakukan seks virtual. Penelitian yang dilakukan di Indonesia juga mendapatkan hasil bahwa dari 238 responden pengakses konten pornografi/seksual yang ditemukan, ada sekitar 175 orang responden berada pada kategori usia emerging adult (18-25 tahun) (Refwan, 2019).

Perilaku cybersex yang semakin berkembang dan sudah menjadi salah satu fenomena dalam masyarakat ini menjadi perlu dan penting untuk diteliti karena dampak negatif yang ditimbulkannya dapat mempengaruhi kehidupan dalam jangka panjang bila tidak segera diatasi. Suatu perilaku dilakukan karena ada faktor penyebab yang melandasinya, tidak terkecuali perilaku cybersex. Perilaku cybersex ini bisa disebabkan oleh beberapa faktor seperti contohnya adalah faktor psikologis. Faktor psikologis memiliki peran dalam menentukan dan mengendalikan perilaku seseorang, sehingga penting untuk mengetahui faktor-faktor tersebut sebagai dasar dalam menyusun langkah-langkah preventif dan intervensi untuk menangani dan mengurangi perilaku bermasalah seperti cybersex ini.

Pentingnya hal tersebut membuat penelitian ini dilakukan dengan tujuan untuk mengetahui faktor psikologis apa yang berhubungan atau berkaitan dengan perilaku cybersex. Tujuan spesifiknya adalah untuk menguji secara empiris apakah ada hubungan antara depresi dengan perilaku cybersex pada emerging adult dan bagaimana arah hubungannya. Definisi dari depresi sendiri adalah pemikiran abnormal seseorang terhadap keadaan dirinya yang dimanifestasikan dengan simtom-simtom menurunnya mood subjektif, rasa pesimis, kehilangan kespontaan dan gejala vegetatif seperti gangguan tidur dan kehilangan berat badan (Beck dalam McDowell \& Newell, 1996). Hipotesis dalam penelitian ini adalah tidak terdapat hubungan antara depresi dengan perilaku cybersex pada emerging adult sebagai $\mathrm{HO}$ dan terdapat hubungan antara depresi dengan perilaku cybersex pada emerging adult sebagai Ha.

\section{Desain Penelitian}

\section{E T O D E}

Penelitian ini menggunakan pendekatan penelitian kuantitatif korelasional. Desain penelitian yang digunakan adalah metode survei cross-sectional. Desain penelitian ini dipilih karena tujuan dari penelitian ini adalah untuk mengetahui apakah ada hubungan antara depresi dengan perilaku cybersex pada populasi emerging adult yang membutuhkan banyak subjek dalam satu waktu dan wilayah yang luas.

Partisipan 
Partisipan yang dibutuhkan dalam penelitian ini adalah laki-laki dan wanita berusia 18-25 tahun. Kriteria partisipan seperti ini dibutuhkan karena usia 18-25 tahun merupakan kategori pengguna internet untuk tujuan seksual terbanyak di Indonesia. Proses pencarian partisipan dilakukan dengan teknik purposive sampling. Partisipan yang memenuhi kriteria penelitian akan mendapatkan undangan untuk berpartisipasi, lalu setelah itu mereka mendapatkan penjelasan mengenai penelitian yang akan mereka jalani. Partisipan berhak memutuskan apakah mereka bersedia untuk ikut dalam penelitian ini atau tidak. Jumlah partisipan yang dibutuhkan dalam penelitian ini adalah sebanyak 150 orang dengan nilai effect size sebesar 0,2 dan nilai statistical power sebesar 0,8, hasil ini didapatkan dari penghitungan menggunakan software G*Power. Pada akhirnya ada 216 partisipan yang bersedia mengikuti penelitian ini $\left(M_{\text {usia }}=20,90 ; S D_{\text {usia }}=1,756\right.$; 56 persen perempuan dan 44 persen laki-laki) dengan latar belakang pendidikan mulai dari SMA hingga bekerja.

\section{Pengukuran}

Penelitian ini menggunakan dua alat ukur dalam bentuk skala yaitu Beck Depression Inventory-II (BDIII) untuk mengukur variabel depresi dan Internet Sex Screening Test (ISST) untuk variabel perilaku cybersex. Skala Beck Depression Inventory-II (BDI-II) terdiri dari 21 aitem dengan 4 pilihan pernyataan mana yang paling sesuai dan dirasakan oleh partisipan, memiliki validitas isi yang baik dan hasil analisis reliabilitas menggunakan teknik Cronbach's alpha menunjukkan hasil yang cukup baik $(\alpha=.773)$. Skala Internet Sex Screening Test (ISST) terdiri dari 22 aitem dengan 2 pilihan jawaban (ya/tidak), memiliki validitas isi yang baik dan nilai koefisien reliabilitas Cronbach's alpha cukup baik $(\alpha=.690)$. BDI-II memiliki nilai 0-3 per aitemnya sehingga skor maksimumnya 63 dan skor minimum 0 , sedangkan ISST bernilai 1 untuk ya dan 0 untuk tidak sehingga skor maksimum yang dapat diperoleh adalah 22 dan skor minimum 0 . Penulis juga melakukan uji asumsi sebelum menlakukan analisis data yaitu berupa uji normalitas dan uji linearitas. Uji normalitas dilakukan menggunakan teknik kolgomorov-smirnov dan didapatkan hasil bahwa tidak ada variabel yang memenuhi asumsi normal $(p<0.05)$, sedangkan data variabel penelitian ini bersifat linear berdasarkan uji linearitas yang dilakukan $(\mathrm{p}>0.05)$.

\section{Analisis Data}

Analisis data dalam penelitian ini menggunakan bantuan program software IBM SPSS Statistic 22 for Windows. Proses analisis data penelitian yang dilakukan adalah uji korelasi dengan teknik Spearman Rho. Teknik ini dipilih karena data dalam penelitian ini hanya memenuhi salah satu uji asumsi klasik sehingga harus menggunakan teknik statitistik non-parametrik.

\section{HAS I L P E N ELIT IAN}

Berdasarkan proses pengambilan data yang sudah dilakukan, penulis mendapatkan beberapa data deskriptif seperti $M_{\text {depresi }}=15,58$ dan $M_{\text {cybersex }}=5,13, S D_{\text {depresi }}=9,907$ dan $S D_{\text {cybersex }}=3,792$. Data deskriptif untuk kategori jenis kelamin perempuan didapatkan nilai $M_{\text {depresi }}=17,09$ dan $M_{\text {cybersex }}=3,90$, sedangkan untuk kategori laki-laki adalah $M_{\text {depresi }}=13,96$ dan $M_{\text {cybersex }}=6,67$. Kategori perempuan memiliki nilai Mean lebih tinggi pada variabel depresi dan kategori laki-laki memiliki nilai Mean lebih tinggi pada variabel cybersex. Pada kategori pendidikan didapatkan data $M_{\text {depresi }}=16,33$ dan $M_{\text {cybersex }}=4,67$ untuk kategori SMA, $M_{\text {depresi }}=15,76$ dan $M_{\text {cybersex }}=5,03$ untuk kategori mahasiswa, $M_{\text {depresi }}=13,35$ dan $M_{\text {cybersex }}=5,47$ untuk kategori bekerja, $M_{\text {depresi }}=15,75$ dan $M_{\text {cybersex }}=6,83$ untuk kategori lain-lain. Nilai Mean depresi paling tinggi adalah kategori SMA dan nilai Mean depresi paling rendah adalah kategori bekerja, sedangkan nilai Mean cybersex paling tinggi adalah kategori lain-lain dan nilai Mean cybersex paling rendah adalah kategori SMA.

Hasil uji korelasi yang sudah dilakukan menunjukkan bahwa depresi berkorelasi secara positif dan cenderung lemah $(r(216)=0,267 ; p<0.05)$ dengan perilaku cybersex. Hal ini menunjukkan bahwa $\mathrm{H}_{0}$ 
ditolak dan $\mathrm{H}_{\mathrm{a}}$ diterima, yang berarti terdapat hubungan antara depresi dengan perilaku cybersex. Arah hubungan yang terjadi juga bersifat positif, yang berarti ketika terjadi peningkatan pada variabel depresi maka akan terjadi peningkatan juga pada variabel perilaku cybersex. Penulis juga melakukan analisis tambahan yaitu uji korelasi antara variabel depresi dengan perilaku cybersex pada kategori jenis kelamin laki-laki dan jenis kelamin perempuan.

Hasilnya adalah $(r(95)=0,263 ; p<0.05)$ pada kategori pria dan $(r(121)=0,414 ; p<0.05)$ pada kategori perempuan. Kategori perempuan memiliki kekuatan korelasi sedang dan lebih kuat daripada kategori laki-laki yang hanya memiliki kekuatan korelasi lemah. Penulis kemudian mencoba untuk melihat hubungan antara kategori depresi rendah, ringan, sedang, dan berat dengan perilaku cybersex pada emerging adult dengan hasil $(r(105)=0,193 ; p<0.05)$ untuk kategori depresi rendah dan $(r(44)=-0,148$; $p>0.05)$ untuk kategori depresi ringan, $(r(38)=0,274 ; p>0.05)$ untuk kategori depresi sedang dan $(r(29)=-0,241 ; p>0.05)$ untuk kategori depresi berat. Berdasarkan hasil tersebut dapat diketahui bahwa hanya kategori depresi rendah saja yang berhubungan secara signifikan dengan perilaku cybersex, sedangkan kategori depresi ringan, sedang, dan berat tidak memiliki hubungan yang signifikan dengan perilaku cybersex.

\section{I S K U S I}

Hal ini menunjukkan bahwa $\mathrm{H}_{0}$ ditolak dan $\mathrm{H}_{a}$ diterima. Hasil analisis data menunjukkan bahwa depresi memiliki korelasi atau hubungan dengan perilaku cybersex pada emerging adult. Hubungan antara variabel depresi dengan perilaku cybersex pada emerging adult berkekuatan lemah dan bersifat positif. Hasil tersebut menunjukkan bahwa semakin tinggi nilai depresi maka perilaku cybersex juga akan mengalami peningkatan. Analisis data lainnya menunjukkan bahwa tidak ada perbedaan atau sama-sama terdapat hubungan antara depresi dengan perilaku cybersex pada emerging adult jenis kelamin laki-laki maupun perempuan, namun kekuatan hubungan yang terjadi pada kategori perempuan lebih kuat daripada yang terjadi pada kategori laki-laki.

Kategori perempuan memiliki kekuatan sedang dan kategori laki-laki memiliki kekuatan hubungan rendah atau lemah. Hasil ini sejalan dengan pernyataan bahwa cybersex berkaitan dengan karakteristik mood atau suasana hati seperti melakukan cybersex guna mengatasi stres maupun depresi (Rimington \& Gast, 2007). Kajian sistematis terkini mengenai penelitian jangka panjang yang terkait problematic internet use termasuk cybersex didalamnya juga menunjukkan bahwa depresi lebih cenderung menjadi prediktor dan bukan menjadi konsekuensi, terkhususnya pada populasi Asia (Anderson, Steen, \& Stavropoulos, 2017). Berdasarkan hal tersebut, penelitian ini selain sesuai dengan hasil-hasil penelitian sebelumnya juga menjadi suatu temuan baru bahwa depresi bisa dikaitkan dengan perilaku cybersex tidak hanya berlaku untuk populasi Eropa atau Asia saja, tetapi hal ini juga bisa berlaku untuk populasi Indonesia.

Kekuatan korelasi atau hubungan secara keseluruhan yang terjadi dalam hasil penelitian ini berada pada tingkatan lemah. Hal ini bisa dikaitkan dan didukung dengan uji korelasi berdasarkan per kategori depresi yang menunjukkan hasil bahwa hanya kategori depresi rendah saja yang berhubungan signifikan, sedangkan tiga kategori depresi lainnya yaitu ringan, sedang, dan berat tidak berhubungan signifikan dengan perilaku cybersex pada emerging adult. Hal ini bisa terjadi karena pada karakteristik depresi rendah tidak ditemukan adanya gangguan dalam fungsi seksual sehingga individu pada kategori ini masih memiliki gairah seksual yang normal, sedangkan individu pada kategori depresi ringan hingga berat ditemukan mengalami penurunan gairah seksual seiring dengan bertambah parahnya tingkat depresi yang dialami (Lourenco, Azevedo, \& Gouveia, 2010). Penelitian ini menghasilkan sesuatu yang berbeda karena hasil penelitian ini menyatakan bahwa semakin tinggi tingkat depresi yang dialami maka cybersex juga akan mengalami peningkatan. Temuan baru lainnya 
adalah bahwa tidak semua tingkatan depresi berhubungan signifikan dengan perilaku cybersex dan turunnya gairah seksual akibat memburuknya depresi juga dapat mempengaruhi cybersex.

Cybersex memang tidak hanya terkait dengan depresi saja, tapi juga terkait dengan variabel dan faktorfaktor psikologis lainnya seperti melegakan perasaan bersalah, perasaan ketidakputusasaan, stres, kecemasan, maupun pelarian dari masalah (Carnes, Delmonico, \& Griffin, 2007). Faktor psikologis lainnya lagi adalah kepribadian, kontrol diri, religiusitas, hingga kecerdasan emosional. Orang dengan masalah emosional atau interpersonal pun, seperti harga diri rendah, kelelahan, kesepian, atau penarikan diri juga dapat memilih untuk menjauh dari dunia sosial dan menggunakan internet termasuk cybersex didalamnya untuk merasa lebih baik. Beberapa hal dan faktor lain yang sudah disebutkan diatas bisa menjadi salah satu bagian yang menyebabkan depresi hanya memiliki hubungan dalam tingkatan yang lemah dengan perilaku cybersex pada emerging adult.

\section{S I M P U L A N}

Kesimpulan dari penelitian ini adalah terdapat hubungan positif yang signifikan dengan kekuatan korelasi lemah antara depresi dengan perilaku cybersex pada emerging adult. Kesimpulan dari hubungan yang bersifat positif ini juga menunjukkan bahwa semakin tinggi tingkat depresi yang dialami makan semakin tinggi juga atau terjadi peningkatan dalam perilaku cybersex. Hal itu juga berarti bahwa hipotesis null $\left(\mathrm{H}_{0}\right)$ ditolak dan hipotesis alternatif $\left(\mathrm{H}_{\mathrm{a}}\right)$ diterima dalam penelitian ini. Penulis juga memberikan saran kepada beberapa pihak seperti peneliti selanjutnya, emerging adult, masyarakat, psikolog \& praktisi psikologi, dan juga pemerintah \& pembuat kebijakan di internet.

Saran bagi peneliti selanjutnya agar bisa menggunakan variabel atau faktor psikologis lainnya seperti self esteem, kontrol diri, kepribadian, dan lain-lain. Berikutnya diharapkan peneliti selanjutnya dapat menggunakan karakteristik populasi dan sampel yang berbeda. Saran bagi emerging adult adalah belajar mengenali diri, mencari lingkungan dukungan sosial yang tepat, melakukan perilaku coping yang positif, lebih bijak dalam menggunakan internet, dan mencari bantuan profesional. Saran bagi masyarakat adalah mengingatkan satu sama lain, mengaktifkan fitur keamanan akses pada gadget, serta melaporkan konten cybersex ke pihak yang berwenang. Saran bagi psikolog dan praktisi psikologi adalah melakukan psikoedukasi mengenai gangguan psikologis seperti depresi dan hal seksual. Saran bagi pemerintah dan pembuat kebijakan di internet adalah untuk memberikan alokasi anggaran untuk psikoedukasi kesehatan mental, meninjau kembali faktor anonimitas dan tingkat kebebasan para pengguna internet, dan juga melakukan tindakan pengawasan, pembatasan, pemblokiran, maupun penegakan hukum jika dibutuhkan bagi konten-konten seksual yang beredar.

\section{UCAPA N T ER I M AKASIH}

Terima kasih kepada keluarga dan teman-teman yang sudah memberikan dukungan dan doa sehingga penulis bisa melakukan dan menyelesaikan penelitian ini dengan baik. Penulis juga tidak lupa mengucapkan terima kasih kepada Bu Hamidah dan Pak Afif selaku dosen penguji yang sudah memberikan saran dan masukan bagi penelitian ini, dan juga seluruh responden yang sudah bersedia menjadi partisipan dan membantu proses pengumpulan data dalam penelitian ini.

\section{DEKLARASI POTENSI TERJADINYA KONFLIK KEPENTINGAN}

Andre Hendarto dan Tri Kurniati Ambarini tidak bekerja, menjadi konsultan, memiliki saham, atau menerima dana dari perusahaan atau organisasi manapun yang mungkin akan mengambil untung dari diterbitkannya naskah ini. 


\section{PUSTAKA ACUAN}

Anderson, E., Steen, E., \& Stavropoulos, V. (2017). Internet use and problematic internet use: A systematic review of longitudinal research trends in adolescence and emergent adulthood. International Journal of Adolescence and Youth, 430-454.

Carnes, P., Delmonico, D., \& Griffin, E. (2007). In The Shadow of The Net:Breaking Free of Compulsive Online Sexual Behavior (2nd Ed). USA: Hazelden Foundation.

Delmonico, D. (1997). Cybersex:High Tech Sex Addiction. Sexual Addiction \& Compulsivity Vol 4 (2), 159-167.

Juditha, C. (2020). Perilaku Cybersex pada Generasi Milenial. Jurnal Pekomnas Vol.5 No.1, 47-58.

Lourenco, M., Azevedo, L. P., \& Gouveia, J. L. (2010). Depression and Sexual Desire : An Exploratory Study in Psychiatric Patients. Journal of Sex \& Marital Therapy Volume 37, 32-44.

McDowell, I., \& Newell, C. (1996). Measuring Health : A Guide To Rating Scales and Questionnaires 2nd Edition. New York: Oxford University Press.

Refwan, A. (2019). Hubungan Big Five Personality Dengan Perilaku Cybersex Pada Emerging Adult. Surabaya: Universitas Airlangga.

Rimington, D., \& Gast, J. (2007). Cybersex Use and Abuse: Implications for Health Education . American Journal of Health Education, 34-40. 